\title{
Relevance of Electronic Resources and Improvement of Access for Effective Distance Learning and Continuing Education Programme
}

\author{
Wisdom 0. Anyim \\ ○https://orcid.org/0000-0002-6234-9289 \\ Rhema University, Nigeria \\ *e-mail: wisdomaris@gmail.com
}

\begin{abstract}
Article Information
Received: November 20, 2020

Revised: December 07, 2020

Accepted: December 09, 2020

Online: March 01, 2021
\end{abstract}

\section{Keywords}

electronic resources; distance

learning; continuing education;

information access; relevance of

electronic resources

\begin{abstract}
This paper investigates the relevance of electronic resources and improved access for effective distance learning and continuing education. The descriptive survey design was adopted for the study. The total population of the study comprises 7,125 registered students of the National Open University of Nigeria. A convenience sampling technique was used to select a sample size of 379 respondents. Structured questionnaires were distributed to the respondents through a research assistant, and only 320 valid responses were returned and used for the study. The study used frequency counts and percentages as statistical measures for data analysis. Findings revealed that students access e-resources regularly. Electronic resources were also relevant as they provide students with up-to-date information, complete information from different sources, speedy and easy access to information, and more. Access to electronic resources can be improved through the following means: provision of useful Internet/server to enhance the accessibility of e-resources, online user guideline for accessing e-resources, creation of user-friendly interfaces for easy access to online contents. It was recommended that audio and video conference chats be made available to students to connect librarians for assistance when the need arises; compulsory user-education and orientation program should also be conducted for students on the use of electronic resources.
\end{abstract}

\section{INTRODUCTION}

The need for quick access to knowledge and increased desire to meet academic scholars' information needs has transformed how information is used. A lot has changed in recent years since the advent of modern technologies in higher learning institutions. The wave of change triggered by the emerging technologies has a tremendous effect on how information is stored, accessed, retrieved, and disseminated, extending to users' information-seeking behavior (Anyim, 2019). Lefuna was cited that in recent times, electronic resources have been identified as the primary source of information in the universities, especially for researchers, including students and teaching staff (Ternenge et al., 2019).

Effective distance learning and continuing education programs require the application and deployment of electronic resources in conducting problem-solving research since research dominates students' activities as the bedrock of learning and professional development (Anyim, 2019). Research is 
an essential aspect of the learning process that is mandatory for every student in the Nigerian higher education system. Students admitted that the distancing learning program at Nigerian universities engages in research and other learning activities that require relevant information resources.

Electronic resources encompass all materials that contain information that can be accessed through digital or online means by the support of computer technologies. The information contained in electronic resources is not different from what is contained in printed versions except on the mode of access, storage, and dissemination. Anyim (2018) defines electronic resources as contents of the information in a format that could be accessed through a computer or machine which in some cases require internet connections; these include CD-ROMs, electronic books (e-books), electronic journals (e-journal), electronic indexes, digital reference materials, online databases, and other e-collection.

Electronic resources could be subscription-based or free access. Distance learning and continuing education programs utilize virtual library resources and the facilities used to access them (W. O. Anyim, 2018). The electronic resources include visual materials, news or other media sources and archives, portals. That provides links relevant to different subject areas, digital referencing digital readers, digital film or video, maps, online or digitized documents, audio materials, data archives, digital facsimiles, curricular materials, and websites created by other faculty or other institutions, personal online diaries and more. Other online information resources include bibliographic databases, electronic reference books, search engines for full-text collections, and digital collections of data and data sets (Harley, 2007). Electronic resources refer to a similar concept as electronic library resources, digital resources, digital materials, and soft library resources.

The emergence of electronic resources in the library has significantly changed users' informationseeking perspective in accessing and retrieving information. Consequently, the conventional information resources that initially constitute the significant repository of knowledge in the library are being converted into electronic format. As a university program is advancing to incorporating distance learning, electronic resource provision becomes a paramount factor to consider first. It facilitates access to quick information through a computer terminal (Viswanathan et al., 2016).

Libraries record significant patronage of electronic resources such as online databases, multimedia resources, CD-ROMs, to other forms of information resources (Singh \& Sharma, 2018). Other electronic resources mostly preferred by distance learners are e-journals, e-books, online databases, and electronic conference proceedings (Amankwah, 2014). Despite the availability of electronic resources for distance learning programs, their suitability and use are an issue for investigation (Alzahrani, 2019).

Institutions for distance learning and continuing education have specific requirements to meet before commencing the electronic libraries that provide and manage electronic resources. Electronic resources as the essential means of information for distance learners should be provided and maintained by the host institutions (Ankrah et al., 2018). Universities that offer distance learning programs provide relevant electronic resources organized in a mechanized way to facilitate users' access to information. The availability of electronic resources is an act of making resources available and creating awareness of their existence to users (Ternenge et al., 2019). Electronic resources available for distance learning are managed and delivered by the institution's libraries provide to the users. They provide authoritative, reliable, accurate, and timely access to information (W. O. Anyim, 2018). Distance learners and continuing education students utilize information communication technologies to access online resources accurate and authoritative information to bridge the physical distance barriers. To maintain an effective distance learning program, electronic resources such as computers and bandwidth are readily available for browsing the internet and downloading files, while an online public access catalog is also provided for access to the library resources (Mesagan et al., 2017).

Students resort to the internet for accessing electronic resources for their learning and research activities. It is a matter of concern to observe that various electronic resources are underutilized by the users (Ubogu, 2006). It may be connected to the study's findings conducted to inadequate computers, poor internet connectivity, limited subscribed titles, power outages, difficulty to access and use, lack of relevant e-resources, and lack of adequate assistance from the library. Iyoro (2004) also added that electronic resources available for the distance learning programs were mostly outdated, and the current ones were not enough for those that need them. 
Electronic resources have reduced the rigors students used to go through in searching for information. They have equally helped distance learners across the world to gain easy access to substantial information reservoirs; quick information; navigation with different search options; easy citations of scholarly works; uploading and updating of information; storing and disseminating information - and many other advantages such as flexibility, time, space, cost-effectiveness, and ease of archiving (Tekale et al., 2012). Also, electronic resources provide accurate and timely information, especially for distance students who depend significantly on the electronic resources for information to champion their research and collaboration with other students across the globe for intellectual growth (Ukpebor, 2012)".

Electronic resources have helped distance learning institutions in various ways but are not limited to reducing pressure on academic libraries for physical storage space for books and journals as it provides unlimited access to digital information for users (Lefuma, 2007). In the contemporary era, users' focus has shifted from traditional library resources to electronic resources as it dominates research activities of distance learners due to its easy-to-use potentials (Hadagali et al., 2012). Academic universities have recently adopted an electronic library section that manages electronic resources and plays a supporting role in effective teaching, learning, and distance learners' research activities (Zhang et al., 2011). It suffices to say that electronic resources are invaluable research tools for students in distance learning institutions from the preceding.

Without doubting the benefits associated with the use of electronic resources, several challenges are also involved in the process. Challenges may differ from one individual's experience to another. As discovered from research, lack of information communication technologies' infrastructure, epileptic power supply, or low electric current to power electronic resources are among the threats to the effective use of electronic resources in Nigeria (Uzoagba, 2019). The challenges to the effective use of electronic resources faced by distance learners are endless. Nevertheless, other factors that hinder the effective use of electronic resources in Nigeria were discovered in literature, including; lack of adequate bandwidth size (for effective internet connectivity) and inadequate software (Igwe, n.d.); lack of human capacity in managing the ICT facilities in the libraries, inadequate library staff, inadequacy in finance or power supply, system law, ICT literacy and ICTs infrastructure (Abiolu et al., 2009).

Consequently, upon the challenges mentioned above, students may likely be deprived of the quality learning experience and education, affecting their job productivity. Perhaps, the initiative and competence to carry out problem-solving academic research to ameliorate socio-economic and national problems may be inhibited due to the inability to use information resources (Olowonefa et al., 2011). Though several studies identified challenges hindering effective use of electronic resources by the students, another study on the perception of users towards the electronic resources in the digital library in the MTN library of the University of Nigeria showed that users are highly aware and satisfied with electronic resources available for their academic program (Ekere et al., 2016). It could be that the above position is connected to the provision of relevant electronic resources, digital infrastructure, steady power supply, and adequate bandwidth size for effective internet services, skilled library staff, and more.

Distance learning and continuing education came into existence in Nigerian universities when the recession was ravaging the economy, and the need to create equal access to education was highly required. Due to the larger population living in the country's remote areas, access to city-based academic institutions becomes difficult. On the other hand, distance learning was introduced for those who joined the workforce without completing their education due to family engagements and difficulty combining their work with studies and others who could not secure admission in the conventional institution of higher learning. Distance learning, continuing education, professional development, and lifelong learning are synonyms that refer to an educational or training process, which is the primary essential tool for an organization to succeed (Laal et al., 2014).

As always being the in most developing countries in Africa, gender inequality deprives a vast number of female folks access to higher education, but with distance learning programs, such groups of people could be enrolled in higher learning institutions. However, other factors led to the introduction of distance learning and continuing education in Nigeria, such as remoteness of localities, physical disabilities, and high tuition fees in most privately owned universities. These and other reasons are responsible for the deprivation of many citizens the opportunity to pursue higher education irrespective 
of their eligibility. Distance learning and continuing education provide avenues for underprivileged citizens to attend higher education. Nigeria is rich with a large deposit of human capital, which should be trained to contribute to its economic development with critical literacy and skills. However, several electronic resources are being put into use for a distance learning program, including e-journals, enewspapers, online public access catalog, CD-ROM database, e-magazines, e-books, online database, eresearch reports, virtual library online, science direct online, and Ebscohost reference databases (Ternenge et al., 2019).

The National Open University of Nigeria is a federal government-owned university established to make education accessible to the masses without a distance barrier. The university serves as a premier distance learning institution providing highly accessible and enhanced quality education anchored by social justice, equity, equality, and national cohesion through a broad reach that transcends all barriers. However, the university is meant to provide practical, cost-effective, flexible learning, which adds lifelong value to quality education for all who seek knowledge. Broader objectives of the National Open University of Nigeria include: enhance more access to education; provide flexible but qualitative education; ensure equity and equality of opportunities in education; provide the entrenchment of a global learning culture; reduce the cost, inconveniences, hassles of access to education and its delivery; enhance education for all and life-long learning; provide broader access to education generally but specifically in university education in Nigeria; provide instructional resources via an intensive use of information communication technologies and provide instructional resources through intensive use of information communication technologies (Ajadi et al., 2008).

The National Open University of Nigeria offers distance and continuing education programs and establishes different study centers across regions with headquarters in Abuja. These study centers serve as the contact venue for students' learning activities. The Abuja study center has a library that supports students and faculty members. The library provides users access to different kinds of information resources in print and electronic formats to support teaching, learning, research, and other academic activities. The university provides reliable internet access through local area networks and wireless connectivity for effective service delivery to distance learners. Several online resources covering academic programs of the university, including e-books, e-journals, e-magazines, audiotapes, virtual library, videotapes, subscribed and open-access databases, video reference tools, and more are made available by the university library to support the learning and research needs of the users (National Open University of Nigeria, 2020)

The primary aim of introducing distance learning and continuing education in the National Open University of Nigeria is to make education accessible to the Nigerian community. Online access to information has become a universally accepted practice for students, faculty, and other academic researchers in recent years. In pursuance of the distance learning and continuing education program, access to electronic/online resources have been provided for the faculty and students to facilitate effective learning outcomes. Rizaldi et al., (2020) opined that distance learning is of different forms, including independent education programs; face-to-face programs held in several places at predetermined times with educational information conveyed and with or without interaction from students. The software is not connecting to a schedule of meetings in one location; distance learning with e-learning, namely online learning based on information technology via the internet, and this learning system can be equipped with complementary modules or books.

Distance learning is characterized by an organization regulating independent learning, learning material conveying through the media, and no direct contact between teachers and students. Distance learning is not without an advantage. Anderson (2008) identifies several advantages of the distance learning process as follows: distance learning can be applied to any situation and condition as long as there is an internet network; students can access online teaching material without any particular restriction; if students need additional knowledge on the content studied, they can easily access the internet; students can study or review lesson materials at any time and anywhere if needed and; both teachers and students can conduct discussions via the internet that many participants can follow, thereby increasing knowledge and broader insights.

However, this study focuses on what can be done for electronic resources to be accessed and utilized without difficulties. It is empirically needful to also assess the relevance of electronic resources 
as this will help the institution know the place of such resources in distance learning and continuing education programs. These factors need to be examined to ensure that distance learning and continuing education in Nigeria attain a successful height. This study is intended to determine possible ways to improve access and utilization of e-resources to meet users' information needs. The primary purpose of this study is to investigate the relevance of electronic resources and improvement of access for effective distance learning and continuing education; hence, the following four research questions:

1. How frequent are access to electronic resources for distance learning and continuing education?

2. What is the relevance of electronic resources for distance learning and continuing education?

3. What are the strategies for improving access to electronic resources?

\section{METHODS}

Research Design

The descriptive survey research design was adopted for the study.

\section{Area of Study}

The study was conducted in Nigeria's north-central region (Federal Capital Territory, Abuja), one of Nigeria's six geo-political regions. This area was chosen because it houses the National Open University of Nigeria's headquarters, the first institution to commence a fully open and distance learning program in the country.

\section{The population of the study}

The study population was 7,125 registered undergraduate and post-graduate students of the National Open University, Abuja study center.

\section{Sample and Sampling Technique}

A convenience sampling technique was used to select a sample size of 379 students from the total population.

\section{An instrument for Data Collection}

The structured questionnaire was used to gather data from the respondents.

\section{Method of Data Collection}

Three hundred and seventy-nine (379) copies of the questionnaire were distributed to the respondents through a research assistant, and 320 copies were completed and considered valid for the study. The other copies were invalid due to incomplete responses.

\section{Method of Data Analysis}

Data collected through questionnaires were analyzed using frequency counts and percentages.

\section{RESULTS}

The data obtained from this study was organized and analyzed using frequency count and percentages, which are presented in tables in line with research questions as follows:

\section{$R_{1}$ : How frequent is the access to electronic resources for distance learning and continuing} education?

Table 1. Frequency of Access to Electronic Resources

\begin{tabular}{|c|c|c|c|c|c|c|c|c|c|}
\hline \multirow{2}{*}{ Items } & \multicolumn{2}{|c|}{ Very regular } & \multicolumn{2}{|c|}{ Regular } & \multicolumn{2}{|c|}{ Irregular } & \multicolumn{2}{|c|}{ Very Irregular } & \multirow{2}{*}{ Decision } \\
\hline & $\mathbf{N}$ & $\%$ & $\mathbf{N}$ & $\%$ & $\mathbf{N}$ & $\%$ & $\mathbf{N}$ & $\%$ & \\
\hline Online databases & 104 & 32 & 145 & 45 & 56 & 18 & 15 & 5 & Regular \\
\hline Search engines & 120 & 36 & 158 & 49 & 30 & 9 & 12 & 4 & Regular \\
\hline
\end{tabular}




\begin{tabular}{|c|c|c|c|c|c|c|c|c|c|}
\hline \multirow{2}{*}{ Items } & \multicolumn{2}{|c|}{ Very regular } & \multicolumn{2}{|c|}{ Regular } & \multicolumn{2}{|c|}{ Irregular } & \multicolumn{2}{|c|}{ Very Irregular } & \multirow{2}{*}{ Decision } \\
\hline & $\mathbf{N}$ & $\%$ & $\mathbf{N}$ & $\%$ & $\mathbf{N}$ & $\%$ & $\mathbf{N}$ & $\%$ & \\
\hline Social media & 92 & 29 & 100 & 31 & 68 & 21 & 60 & 19 & Regular \\
\hline E-journal & 201 & 63 & 70 & 22 & 27 & 8 & 22 & 7 & Very regular \\
\hline E-book & 180 & 56 & 122 & 38 & 12 & 4 & 6 & 2 & Very regular \\
\hline OPAC & 200 & 63 & 100 & 31 & 14 & 4 & 6 & 2 & Very regular \\
\hline Portal & 77 & 24 & 185 & 58 & 30 & 9 & 28 & 9 & Regular \\
\hline Internet & 105 & 33 & 190 & 59 & 15 & 5 & 10 & 3 & Regular \\
\hline Multimedia & 50 & 16 & 60 & 19 & 120 & 36 & 90 & 28 & Irregular \\
\hline Video conferencing & 51 & 16 & 80 & 25 & 109 & 34 & 80 & 25 & Irregular \\
\hline Audio conferencing & 32 & 10 & 86 & 27 & 103 & 32 & 99 & 31 & Irregular \\
\hline
\end{tabular}

Frequency counts and percentages were used to determine the frequency of access to electronic for distance learning. The result in Table 1 shows that $27.2 \%$ of respondents indicated that they access electronic resources very regularly, such as e-journal, e-book, and online public access catalog. $45.4 \%$, on the other hand, access electronic resources regularly, including online databases, search engines, and social media, while the other $27.2 \%$ indicated that their access to electronic resources is irregular, especially on the side of multi-media video and audio conferencing.

$\mathrm{RQ}_{2}$ : What are the relevance of electronic resources for distance learning and continuing education?

Table 2. The Relevance of Electronic Resources for Distance Learning and Continuing Education

\begin{tabular}{|c|c|c|c|c|c|c|c|c|c|}
\hline \multirow{2}{*}{$\begin{array}{c}\text { The Relevance of Electronic } \\
\text { Resources }\end{array}$} & \multicolumn{2}{|c|}{$\begin{array}{l}\text { Strongly } \\
\text { Agree }\end{array}$} & \multicolumn{2}{|c|}{ Agree } & \multicolumn{2}{|c|}{ Disagree } & \multicolumn{2}{|c|}{$\begin{array}{l}\text { Strongly } \\
\text { Disagree }\end{array}$} & \multirow[t]{2}{*}{ Decision } \\
\hline & $\mathbf{N}$ & $\%$ & $\mathbf{N}$ & $\%$ & $\mathbf{N}$ & $\%$ & $\mathbf{N}$ & $\%$ & \\
\hline $\begin{array}{l}\text { It provides more up-to-date } \\
\text { information }\end{array}$ & 200 & 63 & 102 & 32 & 11 & 3 & 7 & 2 & $\begin{array}{l}\text { Strongly } \\
\text { Agree }\end{array}$ \\
\hline $\begin{array}{l}\text { It provides speedy and easy } \\
\text { access to information }\end{array}$ & 198 & 62 & 120 & 38 & 1 & 0 & 1 & 0 & Agree \\
\hline $\begin{array}{l}\text { Increases efficiency in distance } \\
\text { learning }\end{array}$ & 260 & 81 & 40 & 12 & 12 & 4 & 8 & 3 & $\begin{array}{l}\text { Strongly } \\
\text { Agree }\end{array}$ \\
\hline $\begin{array}{l}\text { It makes distance learning } \\
\text { more affording }\end{array}$ & 98 & 31 & 102 & 32 & 112 & 35 & 8 & 3 & Agree \\
\hline $\begin{array}{l}\text { It enhances students' self- } \\
\text { learning }\end{array}$ & 170 & 53 & 140 & 44 & 6 & 2 & 4 & 1 & $\begin{array}{l}\text { Strongly } \\
\text { Agree }\end{array}$ \\
\hline
\end{tabular}




\begin{tabular}{|c|c|c|c|c|c|c|c|c|c|}
\hline \multirow{2}{*}{$\begin{array}{c}\text { The Relevance of Electronic } \\
\text { Resources }\end{array}$} & \multicolumn{2}{|c|}{$\begin{array}{l}\text { Strongly } \\
\text { Agree }\end{array}$} & \multicolumn{2}{|c|}{ Agree } & \multicolumn{2}{|c|}{ Disagree } & \multicolumn{2}{|c|}{$\begin{array}{l}\text { Strongly } \\
\text { Disagree }\end{array}$} & \multirow{2}{*}{ Decision } \\
\hline & $\mathbf{N}$ & $\%$ & $\mathbf{N}$ & $\%$ & $\mathbf{N}$ & $\%$ & $\mathbf{N}$ & $\%$ & \\
\hline $\begin{array}{l}\text { It provides access to unlimited } \\
\text { information from different } \\
\text { sources }\end{array}$ & 202 & 63 & 108 & 34 & 7 & 2 & 3 & 1 & $\begin{array}{l}\text { Strongly } \\
\text { Agree }\end{array}$ \\
\hline $\begin{array}{l}\text { It facilitates synthesis of } \\
\text { information /data from } \\
\text { different sources }\end{array}$ & 126 & 39 & 174 & 54 & 10 & 3 & 10 & 3 & Agree \\
\hline $\begin{array}{l}\text { It provides flexibility of } \\
\text { information to the users }\end{array}$ & 140 & 44 & 158 & 49 & 14 & 4 & 8 & 3 & Agree \\
\hline $\begin{array}{l}\text { It provides round the clock } \\
\text { access to information }\end{array}$ & 300 & 94 & 20 & 6 & 0 & 0 & 0 & 0 & $\begin{array}{l}\text { Strongly } \\
\text { Agree }\end{array}$ \\
\hline $\begin{array}{l}\text { It provides remote access of } \\
\text { information to users }\end{array}$ & 180 & 56 & 121 & 38 & 15 & 5 & 4 & 1 & $\begin{array}{l}\text { Strongly } \\
\text { Agree }\end{array}$ \\
\hline $\begin{array}{l}\text { It provides users opportunity } \\
\text { to share information with } \\
\text { others }\end{array}$ & 151 & 47 & 157 & 49 & 7 & 2 & 5 & 2 & $\begin{array}{l}\text { Strongly } \\
\text { Agree }\end{array}$ \\
\hline
\end{tabular}

As indicated in Table 2, the respondents strongly agreed that electronic resources are relevant in distance learning and continuing education. They strongly agreed that electronic resources provide users with more up-to-date information, increase efficiency in distance learning, enhance self-learning, provide complete information from different sources, provide speedy and easy access to information, and more. As presented in Table 2, electronic resources are useful tools to provide adequate distance learning and continuing education.

RQ3: What are the strategies for improving access to electronic resources?

Table 3: Strategies for Improving Access to Electronic Resources

\begin{tabular}{|c|c|c|c|c|c|c|c|c|c|}
\hline \multirow{2}{*}{ Strategies } & \multicolumn{2}{|c|}{$\begin{array}{l}\text { Strongly } \\
\text { Agree }\end{array}$} & \multicolumn{2}{|c|}{ Agree } & \multicolumn{2}{|c|}{ Disagree } & \multicolumn{2}{|c|}{$\begin{array}{l}\text { Strongly } \\
\text { Disagree }\end{array}$} & \multirow[t]{2}{*}{ Decision } \\
\hline & $\mathbf{N}$ & $\%$ & $\mathbf{N}$ & $\%$ & $\mathbf{N}$ & $\%$ & $\mathbf{N}$ & $\%$ & \\
\hline $\begin{array}{l}\text { Development of online user } \\
\text { guideline for } \\
\text { accessing e-resources }\end{array}$ & 80 & 25 & 144 & 45 & 50 & 16 & 46 & 14 & Agree \\
\hline $\begin{array}{l}\text { Creation of user-friendly } \\
\text { interfaces for easy access to } \\
\text { online contents }\end{array}$ & 117 & 37 & 160 & 50 & 30 & 9 & 13 & 4 & Agree \\
\hline $\begin{array}{l}\text { Provision of online } \\
\text { information literacy platform }\end{array}$ & 97 & 30 & 182 & 57 & 22 & 7 & 19 & 6 & Agree \\
\hline
\end{tabular}




\begin{tabular}{|c|c|c|c|c|c|c|c|c|c|}
\hline \multirow{2}{*}{ Strategies } & \multicolumn{2}{|c|}{$\begin{array}{l}\text { Strongly } \\
\text { Agree }\end{array}$} & \multicolumn{2}{|c|}{ Agree } & \multicolumn{2}{|c|}{ Disagree } & \multicolumn{2}{|c|}{$\begin{array}{l}\text { Strongly } \\
\text { Disagree }\end{array}$} & \multirow[t]{2}{*}{ Decision } \\
\hline & $\mathbf{N}$ & $\%$ & $\mathbf{N}$ & $\%$ & $\mathbf{N}$ & $\%$ & $\mathbf{N}$ & $\%$ & \\
\hline $\begin{array}{l}\text { Display of different types of } \\
\text { information available on the } \\
\text { university library portals }\end{array}$ & 111 & 35 & 190 & 59 & 12 & 4 & 7 & 2 & Agree \\
\hline $\begin{array}{l}\text { Provision of online index and } \\
\text { abstract that provides the } \\
\text { information contained in the } \\
\text { e-resources }\end{array}$ & 80 & 25 & 144 & 45 & 50 & 16 & 46 & 14 & Agree \\
\hline $\begin{array}{l}\text { Notification of users on the } \\
\text { newly arrived e-resources in } \\
\text { the library }\end{array}$ & 97 & 30 & 101 & 32 & 92 & 29 & 30 & 9 & Agree \\
\hline $\begin{array}{l}\text { Provision of improved } \\
\text { internet access to enhance the } \\
\text { accessibility of e-resources }\end{array}$ & 150 & 47 & 120 & 37 & 25 & 8 & 25 & 8 & $\begin{array}{l}\text { Strongly } \\
\text { Agree }\end{array}$ \\
\hline $\begin{array}{l}\text { Provision of technical support } \\
\text { by the university library }\end{array}$ & 135 & 42 & 146 & 46 & 20 & 6 & 19 & 6 & Agree \\
\hline $\begin{array}{l}\text { Training of students on the } \\
\text { use of e-resources }\end{array}$ & 121 & 38 & 134 & 42 & 50 & 16 & 15 & 5 & Agree \\
\hline $\begin{array}{l}\text { Creation of dialogue database } \\
\text { for users-librarians' } \\
\text { interaction }\end{array}$ & 110 & 36 & 188 & 61 & 12 & 5 & 6 & 2 & Agree \\
\hline
\end{tabular}

Access and utilization of electronic resources can be improved through the strategies suggested in Table 3, which include improved internet access to enhance the accessibility of e-resources, development of online user guidelines for accessing e-resources, and creation of user-friendly interfaces for easy access to online contents. The provision of an online information literacy platform displays different types of information available on the university library portals, notifications of users on the library's newly arrived e-resources. The university library also provides technical support, given students' training to use e-resources, provides an online index and abstract that provides the information in the e-resources, and creates a dialogue database for users-librarians' interaction.

\section{DISCUSSION}

\section{Frequency of access to electronic resources for distance learning and continuing education}

The result shows that users access electronic resources regularly, especially the online databases, search engines, social media, portal, and internet; with e-book e-journal, and online public access catalog mostly accessed. However, respondents indicated irregular access to multi-media, video conference, and audio conference resources. The result is in line with Anyim (2020), who discovered that users access electronic resources more frequently, especially the online public access catalog, search engines, and other e-resources, in their quest for information, knowledge, and research data. The result is also in tandem with Iwhiwhu's (2012) 's findings, who observed in their research that users had limited access to a variety of resources, including multi-media resources, web cameras, and audiovisual compare to other digital resources. This study supports Amankwah's (2014) findings, who discovered that distance learners and continuing education students are more familiar with e-journals, e-books, online databases, and electronic conference proceedings for their studies. From the findings of the study 
conducted by Anyim (2020), it was also discovered that students utilize electronic resources to a great extent, especially online databases, search engines, the World Wide Web, e-journal, e-book, OPAC, portal, and e-newspaper/magazine.

\section{The relevance of electronic resources for distance learning and continuing education}

The respondents agreed that electronic resources were relevant in distance learning and continuing education from the study's findings. Specifically, the result showed that electronic resources provide users with up-to-date information; increase efficiency in distance learning; enhance selflearning; provide complete information from different sources; provide speedy and easy access to information more. In line with Damilola's (2013) findings, electronic resources facilitate easy access to information, enhance research activities as complete information from different sources could be retrieved at any time, and enhance the quality of academic and research activity by providing up-to-date information. In support of the findings discovered that using electronic information resources for research and learning makes access to information speedy and comfortable and provides users' roundthe-clock access to users.

\section{Strategies for improving access and utilization of electronic resources}

The study's findings showed that access and utilization of electronic resources could be improved by providing full internet access, developing online user guides to enable users to access e-resources, and developing user-friendly interfaces for easy access to online content. It was also providing online knowledge literacy platforms, showing different types of information accessible on university library portals, notifying new users of e-resources in the library, providing university library technical support.

In line with the findings of Anyim (2018), improving access and utilization of electronic resources is based on the following: information literacy training for users; creation of online instruction or user guidelines on how e-resources could be accessed; displaying online resources on the institutional portal and also designing user-friendly interfaces to access and virtual navigation library. Moreover, Taylor et al., (2013) supported this study's findings by stating that the utilization of electronic resources could be improved when computer-user interfaces are useful for easy information access, adequate training, and development in information literacy for students faculty members. This study will serve as a useful tool for advancing knowledge on the relevance of electronic resources and strategies for improving access to effective distance learning and continuing education program.

\section{CONCLUSION}

Based on the result and discussion, electronic resources are relevant learning tools for distance learning and continuing education process, which users can access through computer devices to obtain information. Students in distance learning mode do most of their studies online, which required unhindered access to online resources. Distance learning could be maintained effectiveness, and efforts should be made to improve access and utilization of electronic resources. How this improvement can be made was among the essential findings of this study. Based on the findings of this study, recommendations are made as follows:

1. Distance learning and continuing education institutions should present electronic resources so users can locate them online with relative ease.

2. There should be a compulsory user education/orientation program for every student concerning the use of electronic resources and,

3. Audio and video conference chats should also be made available to students as a means of connecting librarians for assistance when the need arises

\section{REFERENCES}

Abiolu, O. A., \& Okere, O. O. (2009). Rethinking Information Services in the 21 st Century: A Nigerian Perspective. Libraries Create Futures: Building on Cultural Heritage, 27. Retrieved from https://citeseerx.ist.psu.edu/viewdoc/download?doi=10.1.1.183.2287\&rep=rep1\&type=pdf \#page $=27$ 
Ajadi, T. O., Salawu, I. O., \& Adeoye, F. A. (2008). E-Learning and Distance Education in Nigeria. Online Submission, 7(4). Retrieved from https://eric.ed.gov/?id=ED503472

Alzahrani, J. B. (2019). Use and Impact of Electronic Resources at King Abdulaziz University, Jedda, Saudi Arabia. International Journal of Library and Information Studies, 9(4), 60-66. Retrieved from http://www.ijlis.org/img/2019 Vol 9 Issue 4/60-66.pdf

Amankwah, P. B. (2014). Use of Electronic Resources by Undergraduate Students of the Ghana Institute of Management and Public Administration (GIMPA) [Thesis, University of Ghana, Legon]. Retrieved from http://ugspace.ug.edu.gh/handle/123456789/6989 Retrieved from

Anderson, T. (2008). The Theory and Practice of Online Learning. Athabasca University Press. Retrieved from

https://books.google.com/books?hl=id\&lr=\&id=RifNwzU3HR4C\&oi=fnd\&pg=PA91\&dq=And erson, + T. $+(2008) .+$ The+Theory+and+Practice+of+Online+Learning.+Athabasca+University+ Press\&ots=Sh6lOfQWnx\&sig=sHTClWUbNvq29uB1AHl0kisvmbY

Ankrah, E., \& Atuase, D. (2018). The use of electronic resources by post-graduate students of the University of Cape Coast. Retrieved from

http://ugspace.ug.edu.gh/handle/123456789/27104

Anyim, W. (2020). Knowledge and Use of Information Retrieval Tools By Lawyers at Miyetti Law Abuja, Nigeria. Retrieved from http://www.ijlis.org/img/2020 Vol 10 Issue 1/36-44.pdf

Anyim, W. O. (2018). E-Library Resources and Services: Improvement and Innovation of Access and Retrieval for Effective Research Activities in University E-libraries in Kogi State Nigeria. Library Philosophy and Practice. Retrieved from https://go.gale.com/ps/i.do?p=AONE\&sw=w\&issn=15220222\&v=2.1\&it=r\&id=GALE\%7CA5 $\underline{39387783 \& \text { sid }=\text { googleScholar\&linkaccess }=\text { abs }}$

Anyim, W. O. (2019). Electronic Information Resources for Learning and Research Activities among Undergraduate Students in the University Library. Journal of Computer Science and Technology Studies, 1(1), 28-35. Retrieved from https://alkindipublisher.com/index.php/jcsts/article/view/431

Damilola, O. A. (2013). Use of electronic resources by distance students in Nigeria: The case of the National Open University, Lagos and Ibadan study centers. Library Philosophy and Practice. Retrieved from https://go.gale.com/ps/i.do?p=AONE\&sw=w\&issn=15220222\&v=2.1\&it=r\&id=GALE\%7CA3 $\underline{31807675 \& \text { sid }=\text { googleScholar\&linkaccess }=\text { abs }}$

Ekere, J. N., Omekwu, C. O., \& Nwoha, C. M. (2016). Users' perception of the facilities, resources and services of the MTN digital library at the University of Nigeria, Nsukka. Library Philosophy and Practice. Retrieved from https://go.gale.com/ps/i.do?p=AONE\&sw=w\&issn=15220222\&v=2.1\&it=r\&id=GALE\%7CA4 55185964\&sid=googleScholar\&linkaccess $=$ abs

Hadagali, G., Kumbar, B., Nelogal, S., \& Bachalapur, M. M. (2012). Use of electronic resources by postgraduate students in different universities of Karnataka State. International Journal of Information Dissemination and Technology, 2, 189-195. Retrieved from https://www.researchgate.net/profile/Gururaj Hadagali/publication/283691713 Use of ele ctronic resources by post-

graduate students in different universities of Karnataka State/links/5ebff807a6fdcc90d67 a4ca4/Use-of-electronic-resources-by-post-graduate-students-in-different-universities-ofKarnataka-State.pdf

Harley, D. (2007). Use and Users of Digital Resources. EDUCAUSE Quarterly, 30(4), 12-20. Retrieved from https://er.educause.edu/articles/2007/11/use-and-users-of-digital-resources

Igwe, U. O. (n.d.). Libraries Without Walls and Open and Distance Learning in Africa: The Nigerian 
Experience. Retrieved from https://core.ac.uk/reader/345182440

Iwhiwhu, B. E. (2012). Public library information resources, facilities, and services: User satisfaction with the Edo state central library, Benin-City, Nigeria. Library Philosophy and Practice.

Retrieved from

https://go.gale.com/ps/i.do?p=AONE\&sw=w\&issn=15220222\&v=2.1\&it=r\&id=GALE\%7CA2 92873183\&sid=googleScholar\&linkaccess=abs

Iyoro, A. O. (2004). Serial availability, accessibility and utilization: Perceptions of in-training information professionals in a Nigerian university. The Nigerian Library Link, 11(2), 66-71. Retrieved from http://www.academicjournals.org/app/webroot/article/article1411052520 Quadri\%20et\% 20al.pdf

Laal, M., Laal, A., \& Aliramaei, A. (2014). Continuing Education; Lifelong Learning. Procedia - Social and Behavioral Sciences, 116, 4052-4056. https://doi.org/10.1016/j.sbspro.2014.01.889

Lefuma, S. (2007). Access to and use of Electronic Information Resources in theacademiclibraries of the Lesotho Library Consortium. Unpublished Dissertation Submitted to College of Humanities University of Kwazulu-Natal, South Africa. Retrieved from https://researchspace.ukzn.ac.za/bitstream/handle/10413/14345/Sejane Lefuma 2017.pdf ? sequence $=1 \&$ is Allowed $=\mathrm{y}$

Mesagan, F. O., Anyim, W. O., Ubogu, J. O., \& Echezona, N. P. (2017). Availability and utilisation of information and communication technology resources in Nigerian academic libraries. Book of Abstracts. Journal of Applied Information Science and Technology. Retrieved from http://erjsciences.info/wp-content/uploads/2020/11/7.-Accessibility-and-Utilization-ofWeb-Resources-by-Students-in-FCT-College-of-Education-Zuba.pdf

National Open University of Nigeria (2020). Library. Available at Retrieved from https://nou.edu.ng/directorates/library

Olowonefa, G. S., \& Musa, I. F. (2011). Availability and accessibility of information sources to distance learning students: A case study of university of Abuja. Nigerian Libraries, 44(2), 75-88. Retrieved from https://core.ac.uk/download/pdf/234671811.pdf

Rizaldi, \& Dedi Riyan. (2020). How the Distance Learning can be a Solution during the Covid-19 Pandemic. International Journal of Asian Education, 1(3), 117-124. https://doi.org/10.46966/ijae.v1i3.42

Singh, J., \& Sharma, A. K. (2018). To study the frequency, availability and purpose of using CD-ROMs and Internet resources by the students in Amity University, Jaipur. Library Progress (International), 38(1), 114-122. Retrieved from https://bpasjournals.com/admin/upload/dynamic2/11-Lib-72-2018\%20P 114-122.pdf

Taylor and Francis Group (2013). Facilitating access to Free Online Resources: Challenges and Opportunities for the Library Community. Retrieved June 23, 2020 from http://explore.tandfonline.com/lmt/discoverability

Tekale, R. B., \& Dalve, D. B. (2012). E-resources review of research. Retrieved January 15,2020 from http://www.reviewofresearch.net/ Publish Articles/45.pdf

Ternenge, T., \& Kashimana, F. (2019). Availability, Accessibility, and Use of Electronic Information Resources for Research by Students in Francis Sulemanu Idachaba Library University of Agriculture, Makurdi. Library Philosophy and Practice. Retrieved from https://digitalcommons.unl.edu/cgi/viewcontent.cgi?article=5768\&context=libphilprac

Ubogu, F. N. (2006). Trends in digital library services in academic libraries in South Africa: Library portals and ETD system. Libraries: Dynamic Engines For The Knowledge And Information Society, 6. Retrieved from https://www.academia.edu/download/8850301/abuja2006compedium.pdf\#page=10 
Ukpebor, C. O. (2012). Availability and use of electronic resources in African universities: The Nigerian perspective. PNLA Quarterly, 76(3), 190-199. Retrieved from https://core.ac.uk/download/pdf/234672286.pdf

Uzoagba, N. C. (2019). Availability and Use of Library Resources and Services in National Open University of Nigeria (NOUN). Unpublished Dissertation Submitted to Department of Library and Information Science, University of Nigeria, Nsukka. Retrieved from https://www.unn.edu.ng/publications/files/18309 availability and use of library resource $\underline{\text { s and services in national open university of nigerian (noun) nigeria.pdf }}$

Viswanathan, V., \& Sasireka, I. (2016). Use of Library Electronic Resources Among Selected Arts And Science Colleges In Tamil Nadu. International Journal of Library Science and Research (IJLSR), 6(4), 17-22. Retrieved from https://www.academia.edu/download/49035982/3. IJLSR Use of Library Electronic Resources among Selected1.pdf

Zhang, L., Ye, P., \& Liu, Q. (2011). A survey of the use of electronic resources at seven universities in Wuhan, China. Program, 45(1), 67-77. https://doi.org/10.1108/00330331111107402 